\title{
Marketing Strategy, Competitive Advantage and Marketing Performance : Study of Small Medium- Size Enterprises At Ancol
}

\author{
Maulana Ichsan ${ }^{1 *}$, Naili Farida ${ }^{2}$, Sari Listyorini ${ }^{3}$ \\ Diponegoro University ${ }^{1 * 2,3}$ \\ Corresponding Author: maulanaichsan4@gmail.com ${ }^{1 *}$
}

Keywords: Market Strategy, Competitive Advantage, Marketing Performance

\begin{abstract}
:
This study aims empirical evidence regarding the performance of the marketing effect by the management strategy of the market through the competitive advantages that the statement is sourced from the marketing performance of small medium-size enterprises in the Ancol area as the dependent variable which is influenced by the competitive advantage as an intervening variable and market strategy, as well as research that are new this is the topic under study has never been done by previous researchers. Thus the intent of this research can be called a novelty. The population of this study amounted to 235 of small medium-size enterprises in the region Ancol on the pandemic of Covid-19 by using the formula sample slovin to 70 small medium-size enterprises with a scale of 1 to 10 , the Information of the questionnaire to know the interpretation of the market strategies, competitive Advantage and marketing performance. Analysis techniques for data use regression linear with testing intervening.This research is the implementation of the strategy management market mehasilkan a greater influence on competitive advantage. Strategy management market affect the marketing performance through competitive advantage effective in his work as an intervening variable between the management strategies of the market and marketing performance.
\end{abstract}




\section{Introduction}

The difficulty of Indonesia precisely in the year 2020 at the beginning of march, had entered the pandemic covid-19. there were reports of two (2) findings of 2 (two) cases in Indonesia. However, on 3, 4, and 5 March not found cases of the virus Covid-19. On March 6, found 2 positive cases (source: tirto.id). This has an impact on the economy indonesia on small medium -size enterprises in the tourism sector have a significant impact. The impact resulted in losses on small medium-size enterprises in the area of Tourism. In the pandemic of Covid-19 in indonesia, countless entrepreneurs who have done the Termination of Employment (PHK) against the employee. Official General Labor, Transmigration, and Energy DKI Jakarta, not knowing that countless 162.416 workers in Jakarta experienced a termination of employment (PHK) due to Covid-19. Details, 30.137 workers from 3.348 the organization of the company termination of employment, while the 132.279 workers from 14.697 company laid off without pay. This Info was found after the Manpower has opened a registration Card Programs Prakerja for workers who are laid off and at home date 2-4 April 2020 (Source: Kompas.com).

The impact of the termination of employment by the declining power of the visit and the purchasing power against the perpetrators of small medium-size enterprises of the pandemic Covid-19. With such as conditions, and more people think of the purpose of food every day of their food than to visit and enjoy the souvenir and gifts of found in Ancol. Pandemic Covid-19 is certainly very influential on the industrial sector small medium-size enterprises, given the industrial sector small medium-size enterprise is closely associated with the tourism sector, industry, and culinary.

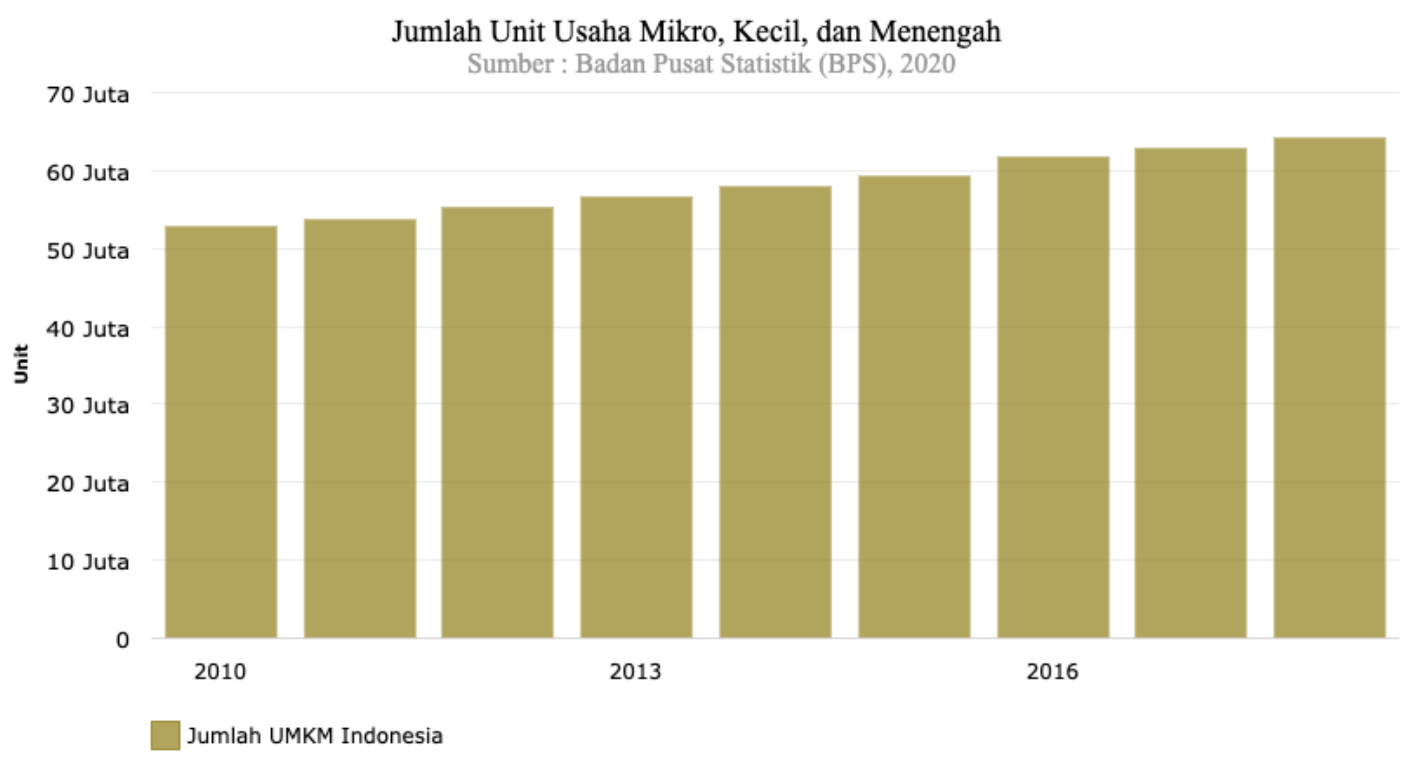

Source: BPS Indonesia 2020

Figure 1. Small Medium-Size Enterprises Total 
In the tourism sector, Indonesia is constrained by the decline in tourist arrivals. The Minister of Cooperatives and Small Medium-Size Enterprise Teten Masduki, argued that the results of the survey by the execution team that had been carried out in the Covid-19 Pandemic Era had a significant impact on the sustainability of Small Medium-Size Enterprises (Cahyani, 2020). There are 47 percent of Small Medium-Size Enterprises that have gone out of business or permanently closed due to the Covid-19 pandemic. Small Medium-Size Enterprises have experienced serious problems in the health of financial cash flows and weakness on the demand side which suppresses the sustainability of Small Medium-Size Enterprises. According to the tourism and creative economy office for the Ancol Region, North Jakarta recorded data on small medium-size enterpises implementing large-scale social restrictions (PSBB) in the Ancol, the source of data from the Ancol manager. provisional results there are around 70 Small MediumSize Enterprises who stop the permanently closed in Ancol.

In pandemic era, for almost a period of 1 year and 6 months, Small Medium-Size Enterprises have difficulty improving their marketing performance from facing conditions that were very different from normal in the previous year. This dynamic condition is very difficult to predict in terms of finance and the economy because have not of the consumers and tourists who visit. Of course, a marketing strategy is needed to deal with this decline during the COVID-19 pandemic. The limited condition of small medium-size enterprises in marketing their products and services is currently still not effective considering the Covid-19 pandemic is still ongoing. The Regional and Central Governments limit the blocking of all these social activities. Therefore, small mediumsize enterprises must be truly innovative in changing their marketing strategy from each product advantage to market it. Like opening a shop at home, before Ancol operated normally. By developing the intelligence of business actors, apart from opening stalls at home, they also take advantage of the online market/called E-Commerce Trade. E-commerce is the use of websites or applications that can be accessed via computers, which are used to obtain information using the internet in the workplace (Kotler \& Armstrong, 2012).

In the era of the Covid-19 pandemic, the income from small medium-size enterprises in trading activities in Ancol decreased. the causes of their financial decline was due to limitations in activities carried out by the government, especially in the Ancol area, Closing Level 4 Application of Community Activity Restrictions (PPKM). For the sake of success in the new normal era and in phase 2 of the Covid-19 Pandemic, small and medium business actors in Ancol, one of which is to build a marketing strategy to have the advantage of their products and services and to be able to differentiate what they sell when they enter the new normal again. their promotion and marketing strategy goes on and on without stopping. This marketing strategy also builds the attractiveness of tourist visits which generates purchasing power in consumer decisions for success and supports small medium-sie enterprises in Ancol. 
Table 1. Reserch Gap

\begin{tabular}{|c|c|c|}
\hline Research & Result & Name \\
\hline $\begin{array}{l}\text { Strategic marketing and } \\
\text { business performance: A study } \\
\text { in three European 'engineering } \\
\text { countries' }\end{array}$ & $\begin{array}{l}\text { Competitive advantage is not statistically } \\
\text { significant in its positive relation to market } \\
\text { performance }\end{array}$ & $\begin{array}{l}\text { Jaakkola M, } \\
\text { Möller K, } \\
\text { Parvinen P et } \\
\text { al (2010) }\end{array}$ \\
\hline $\begin{array}{l}\text { The relationship between } \\
\text { marketing strategies and } \\
\text { performance in an economic } \\
\text { crisis }\end{array}$ & $\begin{array}{l}\text { The study makes some significant } \\
\text { contributions to theory and practice }\end{array}$ & $\begin{array}{l}\text { Köksal \& } \\
\text { MÖzgül E } \\
\text { (2007) }\end{array}$ \\
\hline $\begin{array}{l}\text { Strategi Positioning Dalam } \\
\text { Persaingan Bisnis (Points Of } \\
\text { Difference Dan Points Of } \\
\text { Parity) }\end{array}$ & $\begin{array}{l}\text { Positioning strategy has statically a } \\
\text { significant effect }\end{array}$ & $\begin{array}{l}\text { Heriyadi } \\
\text { (2018) }\end{array}$ \\
\hline $\begin{array}{l}\text { Marketing strategy, contextual } \\
\text { factors and performance: An } \\
\text { investigation of their } \\
\text { relationship }\end{array}$ & $\begin{array}{l}\text { This research also investigated the } \\
\text { relationship between the marketing } \\
\text { strategy variables and organisational } \\
\text { performance The results suggest are } \\
\text { significant. }\end{array}$ & $\begin{array}{l}\text { Sharma B } \\
(2004)\end{array}$ \\
\hline $\begin{array}{l}\text { Market orientation and } \\
\text { performance of export } \\
\text { ventures: The process through } \\
\text { marketing capabilities and } \\
\text { competitive advantages }\end{array}$ & $\begin{array}{l}\text { Market orientation affects the performance } \\
\text { of the export business with the process } \\
\text { through marketing capabilities and } \\
\text { competitive advantage }\end{array}$ & $\begin{array}{l}\text { Janet Y. } \\
\text { Murray, } \\
\text { Gerald Yong } \\
\text { Gao Masaaki } \\
\text { Kotabe } \\
(2011)\end{array}$ \\
\hline
\end{tabular}

Previous research focused on the relationship variables between strategy and marketing performance. but this study tries to investigate the problems that occur due to the covid-19 pandemic focused on small medium-size benterprises with the renewal of the intervening variable as a support for the independent variable against the dependent variable. although this research is still limited to an in-depth context to support successful marketing performance and provide solutions to small medium-size enterprises so that in the explanation related to research, this case is a case to analyze the marketing performance of superior products and services excellent, identify the right target market, which is involved in the activities of small medium-size enterprises and their solutions, business position and contribution. on increase the income of small medium-size enterprises. This research has a purpose and objectivity in marketing strategies in shaping product and service excellence to improve the marketing performance of small medium-size enterprises to be able to survive in the Covid-19 pandemic era. This research is of a renewal nature, namely the topic of research that has never been done by previous researchers and carrying out the development of several research gaps. 
Corona Virus Disease 2019

Covid-19 has become a dangerous case throughout the country, in wuhan is the city where the Covid-19 virus emerged, actually this virus was the beginning of the emergence of reports. So far, the corona virus appeared in China in November 2019. the party will report cases based on clusters within the World Health Organization (WHO) on December 31, 2019 (source: Kompas.com). China's National Health Organization confirmed that Covid-19 can be passed from person to person. Dr. Li clarified the statement in the message that the virus was a different coronavirus. (WHO) said it was possible that the Covid-19 virus was the animal that was the main source of this virus (Source: Merdeka.com).

This pandemic covid-19 has resulted in very dangerous problems, one of which is the economic and financial problems of the entire country. In general, the COVID-19 pandemic has caused the global economy and finances to cripple. Indonesia country is one of the countries whose economy is paralyzed in the tourism sector, especially in the small medium-size enterprises sector which dominates tourist areas in Indonesia. The decline in income in terms of trade and small medium-size enterprises financial is a problem that must be resolved considering that small medium-size enterprises are the economic drivers of finance and trade in the Republic of Indonesia, which absorb a lot of human resources.

\section{Tourism}

The tourism industry sector has proven to be the core and center of the national economy that can increase per capita in Indonesian society, Indonesian tourism has a beautiful tourist attraction and has the potential to be an attraction for domestic and foreign tourists, tourism is a source of foreign exchange for the country, in 2019 the tourism sector contributed income foreign exchange of USD 24 billion, being one of the countries with the best growth over the last four years, in the 2017 Travel event and Tourism Competitiveness Index Report, Indonesia's tourism ranking was ranked 42, in the last year 2019 it rose to rank 40 (Sutono, et al, 2019) .

In the era of the pandemic, a lot of tourism was closed due to the pandemic either permanently or temporarily. Income and a big influence on the Indonesian economy and foreign exchange, this pandemic will be tentative in 2020 - 2021. The closure is due to a precaution taken by the government that can harm tourism, be it government business entities and corporation business entities, etc.

\section{Small Medium-Size Enterprises}

The Based on the Law of the Republic of Indonesia Number 20 of 2008 concerning Micro, Small Medium-Size Enterprises, there are several regulations that are closely related to the implementation of Sustainable Finance in Indonesia. Some of the points of the regulation consist of the following articles: Chapter II Principles and Objectives Article 2 stipulates that micro, Small and Medium Enterprises are based on an environmental perspective. What is meant by "principle 
of environmental insight" is the principle of empowerment of Micro, Small, and Medium Enterprises which is carried out by still paying attention to and prioritizing the protection and maintenance of the environment, Chapter VI Article 20 stipulates that the Government and Regional Governments facilitate business development with incentives for Micro, Small and Medium Enterprises and develop technology and environmental conservation life, Chapter VII Financing and Guarantee Article 22 explains that in order to increase sources of financing for Micro and Small Businesses, the Government shall make efforts: Development of financing sources from bank credit and non-bank financial institutions; Development of venture capital institutions; Institutionalization of factoring transactions (Source: ojk.go.id)

The Covid-19 Pandemic era, so many small medium-size enterprises players or other businesses were complain their business performance that had opened a business and built it for a long time. The Ministry of Cooperatives and small medium-size enterprises released an e-form for the benefit of collecting data on cooperatives and bussiness man who affected by the Covid19 pandemic. This data collection is a complaint against small medium-size enterprises as a basis for preparing the right strategy (Source: KOMENKOPUKM.go.id). It was recorded that around 37.000 small medium-size enterprises reported on the e-form data collection. The impact that appears is a decrease in sales due to the implementing large-scale social restrictions (PSBB) carried out by the central government so that consumers can only confine themselves at home and some small medium-size enterprises have limited capital due to declining sales.

\section{Marketing Performance}

The opinion of (Kotler and Keller, 2012) Marketing Performance means the evaluation and measurement of the achievements of a company derived from the planning, design and application of marketing strategies and competitive advantages possessed by the company. Marketing performance is a success due to an increase in market share, profits, margins and distribution of a product or service offered by consumers.

The opinion to Ferdinand in (Jasmani, 2018) argues that "marketing performance is a factor that is often used to measure the impact of strategies implemented by companies to produce optimal marketing performance". Marketing performance indicators are measured through: sales volume, company customer growth, and profit capability, namely the amount of profit the company gets.

Sales volume of opinion to Budidharmo (in Hartini, 2020), "is the total sales obtained from an item obtained from a certain period". While the sales volume according to Abdullah (in Hartini, 2020), "is the number of units sold from the production unit, a transfer from the producer to the consumer, and remains for a certain period".

"Customer growth is an advantage, increasing the level of effective service from various types of facilities that overall affect the level of customer growth" (in Lely \& Adi, 2016). 
"Profitability is to give a real picture of the company and its ability to survive in the future. The significance of earning ability comes from the profit where many parties make their decisions" (in M \& Laksito, 2017).

\section{Marketing Strategy}

The marketing management book, (Kotler and Keller, 2012) suggests that all marketing strategiy made based on market segmentation, target market and positioning (STP) of a product or service where the target is right. The company finds solutions to various needs and groups of people in the market, targets what can strongly satisfy the Organization, and then positions the offer so that the target market recognizes the bargaining power and image of a company. The research (Sri and Nuri, 2022) according to (Kotler, 2012) there are 3 components in marketing design, namely segmenting, targeting, and positioning. Market segmentation is an activity to divide the consumer market into different groups. Consumers who have the same or almost the same characteristics of each from a group. (Sofjan Assauri, 2015). Targeting is an activity that determines the target market, namely the act of selecting one or more segments to serve. Evaluating, selecting, selecting, and reaching consumers who will be targeted is targeting. (Kotler, 2008). According to (Tjiiptono and Chandra, 2012) positioning is an action or steps taken by a company in an effort to offer value where consumers understand and appreciate what a company does compared to its competitors in one segment. trying to instill the image of the product in the minds of consumers in the selected segment.

The marketing strategy of a company or business has a function as a determinant of the economic value of the company in the form of products and services. There are 3 factors that determine this, namely production, marketing, and consumption. So it can be said that the marketing strategy is the link between production and consumption.

$H_{1}$ : Market strategy directly affects competitive advantage.

\section{Competitive Advantage}

The Based on Yahya's opinion (Yahya, 2014), the implementation of a perfect competitive advantage strategy will form superior customer value, both in the form of relatively low costs and unique benefits. Furthermore, superior customer value will increase the satisfaction of the target market using which will convey a positive response in the form of increasing the number of customers who use and are loyal to the company's products, because the higher perceived value comes from a competitive advantage strategy product and services.

Achievements in sustainable competitive advantage in research (Rosmayani and Annisa, 2021) according to (Barney, 2007), determined the role of resources consisting of human capital, structural capital and relational capital to create value that is beneficial to consumers, difficult to imitate by its competitors and supported by company management. Market-oriented companies will focus on external needs, wants and market demands. This is the organizational culture and 
the basis for the bussiness strategy to achieve the business goals. In order to support a marketoriented business culture. This is important to be a continuous learning process for bussiness to provide more and different added value for customers. In particular, this becomes very important when market conditions face very high competition which causes Small Medium-Size Enterprises to need to implement innovative product strategies to be able to compete in providing customer satisfaction.

Small medium-sized enterprises ancol a product innovation is often due to errors in product design, inaccurate predictions of competition, expensive production costs beyond the previously estimated calculations. Slow in making changes to product innovation that is not in line with the growth of a product on the market is also the reason for the failure of Small mediumsized enterprises.

$\mathrm{H}_{2}$ : Market strategy indirectly affects marketing performance through competitive advantage.

\section{Research Method}

The method used is a quantitative method to analyze the independent variable, the dependent variable and the intervention variable. This method aims to explain hypothesis 1 is Market strategy directly affects competitive advantage and hypothesis 2 is Market strategy indirectly affects marketing performance through competitive advantage.

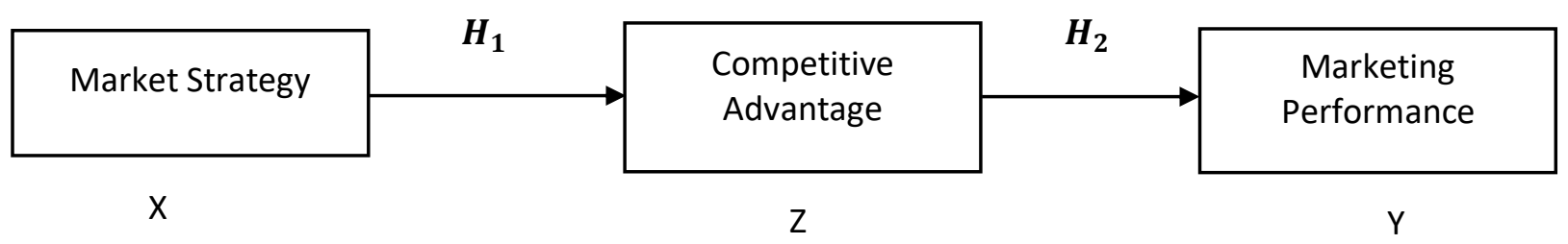

Figure 2. Path Framework

The technique in this research sample uses a probability sampling technique, precisely using a random sample method, the namely participants in the sample randomly without being shown the strata in the population and spreading through online-based technology (google form). Data processing using SPSS 25.0 application. Sample criteria The population of this study amounted to 235 small and medium businesses in the Ancol of the Covid-19 pandemic using the slovin sample formula to be 70 small medium-size enterprises in the Ancol .

$$
\begin{array}{ll}
\eta & =\frac{N}{1+\left(N \times e^{2}\right)} \\
\eta & =\frac{235}{1+235(0,1)^{2}}
\end{array} \quad \eta=\frac{235}{3,35}=70 \text { Sample }
$$


Questionnaire Scale of Measurement

The measurement in using research questionnaires to be able to find out the responses of small medium-size enterprisesrespondents to phenomena related to the variables of this research, namely marketing strategy, competitive advantage and marketing performance. The questionnaire technique is distributing questionnaires with the answers using a Likert scale with answers from 1 to 10 which means how much do small and medium business actors agree with the appropriate answer points during the conditions and circumstances when the pandemic covid 19 is approaching the new normal era. This questionnaire contains content which is divided into two parts. The first part contains data on respondents from small and medium business owners in Ancol (name, gender, type of SME, time of starting a business). The second part contains a point of statements related to this research. Respondents or small medium-size enterprises need 5-10 minutes to fill out the statement.

\section{Result and Discussion}

This research has resulted from statistical analysis tools that from 235 small medium-size enterprises using the slovin formula to 70 respondents are small medium-size enterprises in Ancol which have entered the second vaccine stage and second fase of the Covid-19 pandemic. there are 53 men (76\%) and 17 women (47\%), Types of business include 33 Culinary (47\%), 11 Clothing (16\%), 10 Souvenirs (14\%) and 16 Others (23\%). The length of time the business was established in the Ancol area were 15 people < 1 year (21\%), 25 people 1 - 5 years (36\%) and 30 people $>5$ years $(43 \%)$.

Table 2. Respondents Profile

\begin{tabular}{cccc}
\hline Features & Category & Frequency & Presentage (\%) \\
\hline \multirow{2}{*}{ Gendre } & Male & 53 & $76 \%$ \\
\cline { 2 - 4 } & Female & 17 & $24 \%$ \\
\hline \multirow{4}{*}{ Type of Business } & Culinary & 33 & $47 \%$ \\
\cline { 2 - 4 } & Clothing & 11 & $16 \%$ \\
\cline { 2 - 4 } & Souvenirs & 10 & $14 \%$ \\
\cline { 2 - 4 } & Others & 16 & $23 \%$ \\
\hline \multirow{3}{*}{ Estabilished since } & $<1$ Year & 15 & $21 \%$ \\
& $1-5$ Year's & 25 & $36 \%$ \\
& $>5$ Year's & 30 & $43 \%$ \\
\hline
\end{tabular}




\section{Validity Test Result}

\section{Table 3. Market Strategy Validity Result}

\begin{tabular}{|c|c|c|c|c|c|}
\hline \multicolumn{6}{|c|}{ Correlations } \\
\hline & & Market Strategic 1 & Market Strategic 2 & Market Strategic 3 & $\begin{array}{l}\text { Total Market } \\
\text { Strategic }\end{array}$ \\
\hline \multirow[t]{3}{*}{ Market Strategic 1} & Pearson Correlation & 1 & $.710^{\star \star}$ & $.632^{\star \star}$ & $.889^{\kappa \times}$ \\
\hline & Sig. (2-tailed) & & .000 & .000 & .000 \\
\hline & $\mathrm{N}$ & 70 & 70 & 70 & 70 \\
\hline \multirow[t]{3}{*}{ Market Strategic 2} & Pearson Correlation & $.710^{\star \star}$ & 1 & $.607^{\star \star}$ & $.880^{\mathrm{x}}$ \\
\hline & Sig. (2-tailed) & .000 & & .000 & .000 \\
\hline & $\mathrm{N}$ & 70 & 70 & 70 & 70 \\
\hline \multirow[t]{3}{*}{ Market Strategic 3} & Pearson Correlation & $.632^{\kappa \star}$ & $.607^{\star \star}$ & 1 & $.857^{\star \star}$ \\
\hline & Sig. (2-tailed) & .000 & .000 & & .000 \\
\hline & $\mathrm{N}$ & 70 & 70 & 70 & 70 \\
\hline \multirow[t]{3}{*}{ Total Market Strategic } & Pearson Correlation & $.889^{* \star}$ & $.880^{\kappa *}$ & $.857^{\star \star}$ & 1 \\
\hline & Sig. (2-tailed) & .000 & .000 & .000 & \\
\hline & $\mathrm{N}$ & 70 & 70 & 70 & 70 \\
\hline
\end{tabular}

**. Correlation is significant at the 0.01 level (2-tailed).

Source: Primary data processing SPSS 25.0 results

Table 4. Competitive Advantage Validity Result

\section{Correlations}

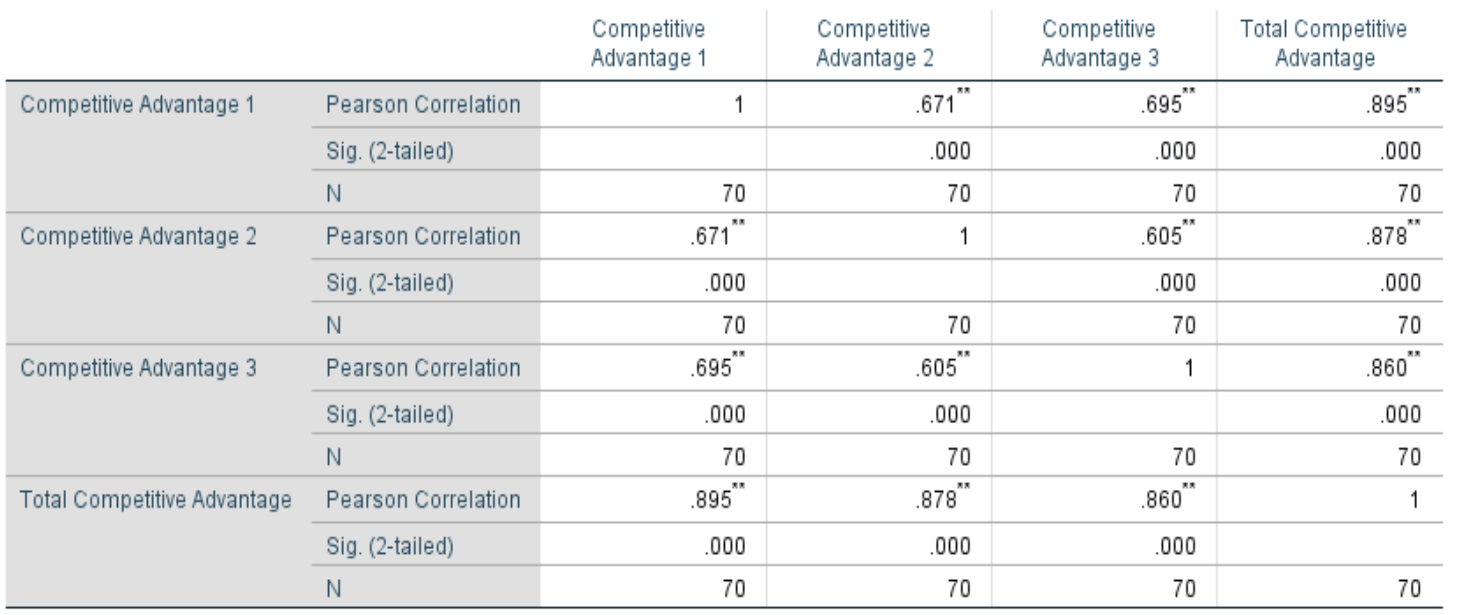

**. Correlation is significant at the 0.01 level (2-tailed).

Source: Primary data processing SPSS 25.0 results 
Table 5. Marketing Performance Validity Result

\begin{tabular}{|c|c|c|c|c|c|}
\hline \multicolumn{6}{|c|}{ Correlations } \\
\hline & & $\begin{array}{c}\text { Marketing } \\
\text { Performance } 1\end{array}$ & $\begin{array}{c}\text { Marketing } \\
\text { Performance } 2\end{array}$ & $\begin{array}{c}\text { Marketing } \\
\text { Performance } 3 \\
\end{array}$ & $\begin{array}{c}\text { Total Marketing } \\
\text { Performance }\end{array}$ \\
\hline \multirow[t]{3}{*}{ Marketing Performance 1} & Pearson Correlation & 1 & $.864^{\mathrm{N}}$ & $.541^{* \pi}$ & $.907^{\mathrm{M}}$ \\
\hline & Sig. (2-tailed) & & .000 & .000 & .000 \\
\hline & $\mathrm{N}$ & 70 & 70 & 70 & 70 \\
\hline \multirow[t]{3}{*}{ Marketing Performance 2} & Pearson Correlation & $.864^{\mathrm{N}}$ & 1 & $.661^{*}$ & $.945^{\prime \prime}$ \\
\hline & Sig. (2-tailed) & .000 & & .000 & .000 \\
\hline & $\mathrm{N}$ & 70 & 70 & 70 & 70 \\
\hline \multirow[t]{3}{*}{ Marketing Performance 3} & Pearson Correlation & $.541^{\mathrm{N}}$ & $.661^{\star *}$ & 1 & $.818^{\prime \prime}$ \\
\hline & Sig. (2-tailed) & .000 & .000 & & .000 \\
\hline & $\mathrm{N}$ & 70 & 70 & 70 & 70 \\
\hline \multirow[t]{3}{*}{ Total Marketing Performance } & Pearson Correlation & $.907^{\mathrm{N}}$ & $.945^{\mathrm{kn}}$ & $.818^{\mathrm{kN}}$ & 1 \\
\hline & Sig. (2-tailed) & .000 & .000 & .000 & \\
\hline & $\mathrm{N}$ & 70 & 70 & 70 & 70 \\
\hline
\end{tabular}

**. Correlation is significant at the 0.01 level (2-tailed).

Source: Primary data processing SPSS 25.0 results

The Based on the opinion expressed by (Sugiyono, 2014) the instrument that has a valid value is the sense of measurement used to measure research data. Valid means that the instrument can be used to measure what should be measured in the study.

The table data above produces a test of the validity of the market strategy, competitive advantage and marketing performance variables. It is known that all items from the statements given by the respondents form an $r$ arithmetic value $>$ from $r$ table (0.198) using a significant value $<0.1$ as the result of the three statement items in each variable, both independent variables, dependent variables and intervention variables stated valid results.

Reliability Test Result

Table 6. Market Strategy Reliability Result

\begin{tabular}{|c|c|c|}
\hline \multicolumn{3}{|c|}{ Reliability Statistics } \\
\hline Cronbach's Alpha & $\begin{array}{l}\text { Cronbach's Alpha } \\
\text { Based on } \\
\text { Standardized Items }\end{array}$ & $\mathrm{N}$ of Items \\
\hline .847 & .848 & 3 \\
\hline
\end{tabular}

Source: Primary data processing SPSS 25.0 results

Table 7. Competitive Advantage Reliability Result

\section{Reliability Statistics}

\begin{tabular}{|c|c|c|}
\hline Cronbach's Alpha & $\begin{array}{l}\text { Cronbach's Alpha } \\
\text { Based on } \\
\text { Standardized Items }\end{array}$ & $\mathrm{N}$ of Items \\
\hline .848 & .852 & 3 \\
\hline
\end{tabular}

Source: Primary data processing SPSS 25.0 results 
Table 8. Marketing Performance Reliability Result

\section{Reliability Statistics}

\begin{tabular}{|c|c|c|}
\hline Cronbach's Alpha & $\begin{array}{l}\text { Cronbach's Alpha } \\
\text { Based on } \\
\text { Standardized Items }\end{array}$ & $\mathrm{N}$ of Items \\
\hline .868 & .869 & 3 \\
\hline
\end{tabular}

Source: Primary data processing SPSS 25.0 results

The Based on the results of the data in the table above, the reliability can be seen that all components of the statement indicator variables in this study have proven results that the Cronbach's Alpha value of each variable has a value $>0.20$ in this research.

\section{Classic Assumption Test Result}

Normality Test Result

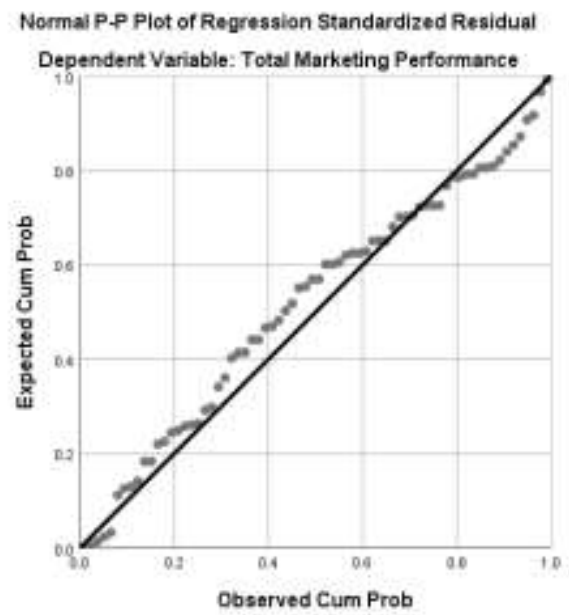

Source: Primary data processing SPSS 25.0 results

Figure 3. P-P Plot (X Indirecty affected $Y$ Through $Z$ )

The based on expert opinion (Ghozali, 2016) The research objective of the normality test is to find out whether the research data in the regression equation obtained is normally distributed and not normally distributed.

The results of the research data are declared normal because a plot follows a diagonal line, therefore research on the data can guarantee a normal distribution, cause of $X$ (independent variable) affects $Y$ (dependent variable) indirectly through $Z$ (intervening variable). 
Heteroscedasticitiy Test Result.

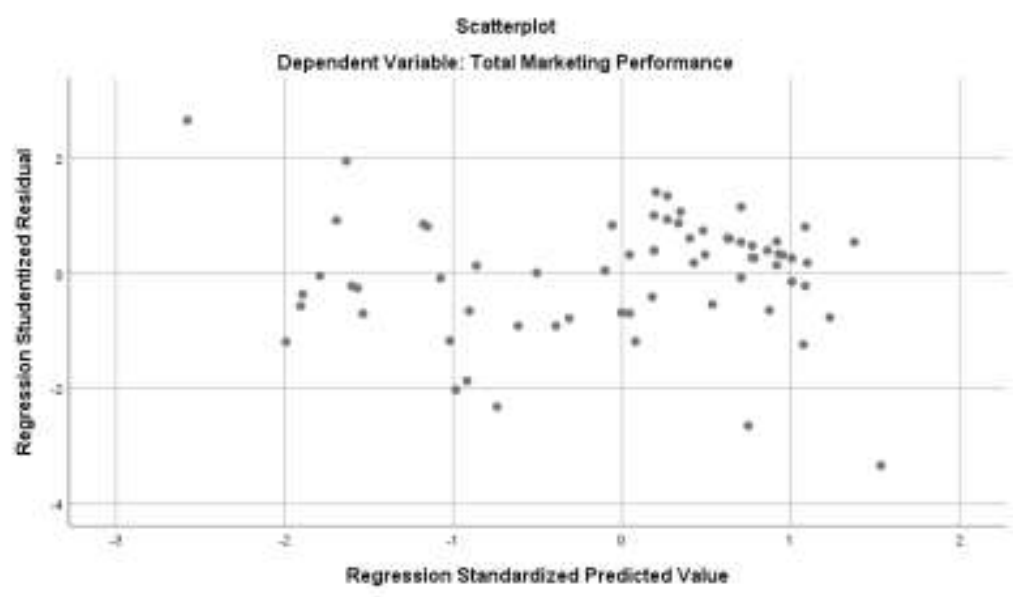

Source: Primary data processing SPSS 25.0 results

Figure 4. Scatter Plot (X Indirecty affectsd Y Through Z)

The based on expert opinion (Ghozali, 2016) the heteroscedasticity test is to test whether in the regression model there is an inequality of variance and residuals from one observation to another.

The data in this research are not stated to be heteroscedastic, which means that the plots are scattered and unformed and unclear (residual inequality). because $X$ (independent variable) has an indirect effect on $Y$ (dependent variable) and through variable $Z$ (intervening variable).

Multicollinearity Test Result

Table 9. X Indirecty affectsd Y Through Z

\begin{tabular}{|c|c|c|c|c|c|c|c|c|}
\hline \multicolumn{9}{|c|}{ Coefficients $^{\mathrm{a}}$} \\
\hline & & \multicolumn{2}{|c|}{ Unstasda!teed Coeffients } & \multirow{2}{*}{$\begin{array}{l}\text { Steniardized } \\
\text { Coeficiants } \\
\text { geth }\end{array}$} & \multirow[b]{2}{*}{1} & \multirow[b]{2}{*}{ Sig } & \multicolumn{2}{|c|}{ Colinearty Stedistics } \\
\hline Nod:1 & & B & Sy Erop & & & & Tolerante & $\sqrt{F}$ \\
\hline \multirow[t]{3}{*}{1} & (Canstart) & $-195 \pi$ & 3396 & & -592 & 556 & & \\
\hline & Tstal Valet Stalegi: & 351 & 159 & 240 & 22204 & 091 & 687 & 1.456 \\
\hline & Total Consedtis Asiartage & .650 & .138 & .512 & 4.710 & 020 & .687 & 1.456 \\
\hline
\end{tabular}

Source: Primary data processing SPSS 25.0 results

The based on the results of research data stated that the value of VIF $<10$ and tolerance value $>0.10$. This Research results that there is no multicollinearity problem in the regression model, therefore this study meets the requirements of regression analysis. 
Intervening Test Result

$$
e=\sqrt{1-0,646}=0,595 \quad e=\sqrt{1-0,457}=0,737
$$

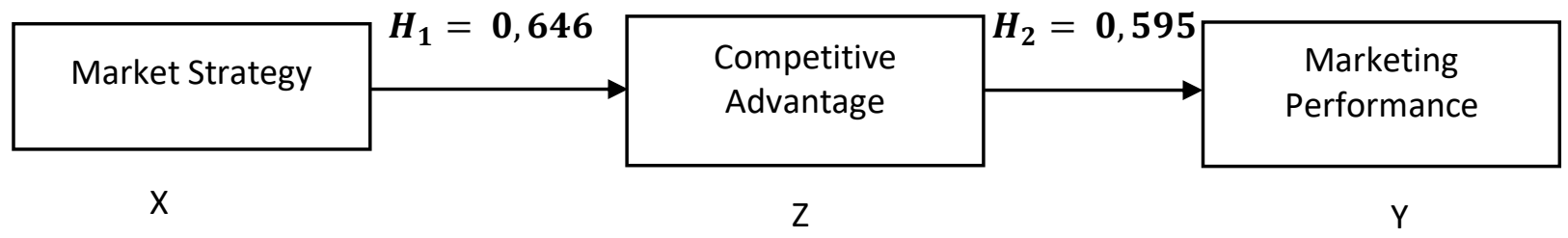

Figure 5. Path Analyze

The results of this research show of path analysis frame work data research which is $X$ (independent variable) In the results of this research that $X$ (independent variable) could also affect $Y$ (independent variable) indirectly through $Z$ as the Intervening Variable. the indirect effect is $H_{1} \times H_{2}=(0.646 \times 0.650)=0.4199$. From the data in the analysis of the research path above, a significant value is obtained, the indirect impact of $X$ on $Y$ through $Z$ means $0.000<0.1$ as a result it can be concluded that the $X$ variable (independent variable) on $Y$ (dependent variable) have an indirect effect through $Z$ as Intervening Variable.

\section{T-Test Result}

Table 10. (X Indirecty affectsd Y Through Z)

\begin{tabular}{|c|c|c|c|c|c|c|}
\hline \multicolumn{7}{|c|}{ Coefficients $^{a}$} \\
\hline \multirow[b]{2}{*}{ Hodel } & & \multicolumn{2}{|c|}{ Unstandardized Coefficients } & \multirow{2}{*}{$\begin{array}{c}\text { Standardiced } \\
\text { Coefficients } \\
\text { Geta }\end{array}$} & \multirow[b]{2}{*}{$t$} & \multirow[b]{2}{*}{$\mathrm{Sig}$} \\
\hline & & $B$ & SH Ener & & & \\
\hline \multirow[t]{3}{*}{1} & (Constant) & -1.957 & 3.306 & & -.592 & 556 \\
\hline & Tota Narket Strategic & .351 & 159 & .240 & 2204 & 031 \\
\hline & Tota Combestive Advantage & 650 & 138 & .512 & 4710 & .000 \\
\hline
\end{tabular}

Source: Primary data processing SPSS 25.0 results

The Based on the results of the research in the table above, it shows that the value of $t$ count >t table $(2.204>1.668)$, then it can be said that hypothesis 1 (one) is accepted. While the variable $Z$ (intervention variable) in hypothesis 2 (two) $t$ value $>t$ table $(4.710>1.668$ ) so it can be said that hypothesis 2 (two) is accepted. 
F-Test Result

Table 11. (X Indirecty affectsd Y Through Z)

\begin{tabular}{|c|c|c|c|c|c|c|}
\hline \multicolumn{7}{|c|}{ ANOVA $^{a}$} \\
\hline Model & & Sum of Squares & $\mathrm{df}$ & Mean Square & $\mathrm{F}$ & Sig. \\
\hline \multirow[t]{3}{*}{1} & Regression & 1378.792 & 2 & 689.396 & 28.138 & $.000^{\mathrm{b}}$ \\
\hline & Residual & 1641.551 & 67 & 24.501 & & \\
\hline & Total & 3020.343 & 69 & & & \\
\hline
\end{tabular}

a. Dependent Variable: Total Marketing Performance

b. Predictors: (Constant), Total Competitive Advantage, Total Market Strategic

Source: Primary data processing SPSS 25.0 results

The based on the results of the research in the table above, it shows that the calculated $\mathrm{F}$ value $>$ the table $F$ value $(28.138>3.984)$ and the significance result $(0.000)<0.1$. So it can be said that the market strategy has a simultaneous and significant effect on Marketing Performance through Competitive Advantage.

\section{Discussion}

This research to improve and produce good marketing performance through competitive advantage with marketing strategy. These results indicate that improving marketing performance requires a perfect marketing strategy. While the results of testing marketing strategies on marketing performance through competitive advantage also indirec or intervening by competitive advantage has a significant effect. This result is in line growth with the findings in the field during the second phase of the COVID-19 pandemic in Ancol.

\section{Conclusion}

The case of this research is an activity to find out how the influence of market strategy on marketing performance through competitive advantage in the COVID-19 pandemic phase 2 . The questionnaire is a tool used to determine the indicators and factors that affect marketing performance. A total of 70 questionnaires were given to respondents with the type of business, namely culinary, clothing, souvenirs and others. The results of the study did not directly have a significant effect on marketing performance in the Ancol tourist area.

The limitations in this research are still not being able to carry out demand actions on respondents in supporting small medium-size enterprises activities in Ancol. but with this research the government will be aware of and see complaints from several small medium-size enterprises who carry out business activities. The research will be further developed in marketing performance by adding market orientation to small medium-size enterprises and conducting 
education on innovative products and services to be able to harmonize and stimulate marketing performance

\section{Acknowledgement}

I would like to thank you my supervisor Prof. Naili Farida and Mrs. Sari Listyorini, as well as the management of Ancol and Mr. Fahrudin as the responsibility of the vice chairman of the small medium- enterprises cooperative in Ancol.

\section{References}

Ardi Priyatno Utomo. 2020. "Virus Corona Diperkirakan Muncul di Wuhan sejak Agustus 2019". Jakarta. https://www.kompas.com/global/read/2020/06/09/201844870/virus-coronadiperkirakan-muncul-di-wuhan-sejak-agustus-2019?page=all.

Budhi Firmansyah Surapati. Rabu, 07 Oktober 2020 14:57. Sudin Parekraf Jakut Data Pelaku Usaha di Ancol. Jakarta https://www.beritajakarta.id/read/83591/sudin-parekraf-jakutdata-pelaku-usaha-di-ancol\#.YVmkwG1By3J

Cahyani, D. R. (2020). 47 Persen UMKM Bangkrut Akibat Pandemi Corona. Tempo. https://bisnis.tempo.co/read/1344540/47persen-umkm-bangkrut-akibatpandemicorona/full\&view=ok

Dewi Retno Dumilah. 2021. PERAN EKONOMI KREATIF DALAM MENINGKATKAN INDUSTRI PARIWISATA DI SEAWORLD ANCOL. Jakarta. JUMPA

Diosdad, Arnol. 2003. Analisis Pengaruh Orientasi Pasar, Teknologi dan Lingkungan melalui Kinerja Pemasaran Untuk Meningkatkan Keunggulan Bersaing. Jurnal. Semarang.

Fellyanda Suci Agiesta. 2020. Cerita Lengkap Asal Mula Munculnya Virus Corona di Wuhan. Jakarta. https://www.merdeka.com/dunia/cerita-lengkap-asal-mula-munculnya-viruscorona-di-wuhan.html

Ghozali. (2016). Aplikasi Analisis Multivariete Dengan Program IBM SPSS. Semarang: Badan Penerbit Universitas Diponegoro.

Heriyadi. 2018. STRATEGI POSITIONING DALAM PERSAINGAN BISNIS (POINTS OF DIFFERENCE DAN POINTS OF PARITY). Yogyakarta. Universitas Muhammadiyah.

Jaakkola M, Möller K, Parvinen P et al . 2010. Strategic marketing and business performance: A study in three European 'engineering countries'. Industrial Marketing Management.

Janet Y. Murray., et,al . 2011. Market orientation and performance of export ventures:the process through marketing capabilities and competitiveadvantages. Journal of the Academy of Marketing Science.

Kanada Kurniawan. 2021. Pengertian Strategi Pemasaran. Jakarta. https://projasaweb.com/pengertian-strategi-pemasaran/ 
Kemenkop UKM. 2021. KEMENKOP DAN UKM RILIS E-FORM PENDATAAN KUMKM TERDAMPAK COVID-19. Jakarta. https://kemenkopukm.go.id/read/kemenkop-dan-ukm-rilis-e-formpendataan-kumkm-terdampak-covid-19.

Kemenpar. 2019. RENCANA STRATEGIS PENGEMBANGAN PARIWISATA HALAL 2019-2024. Jakarta. Deputi Bidang Pengembangan Industri dan Kelembagaan Kementerian Pariwisata.

Köksal \& MÖzgül E. 2007. The relationship between marketing strategies and performance in an economic crisis. Marketing Intelligence and Planning.

Kotler dan Keller. 2012. Marketing Management. New Jersey. Pearson.

Menurut Kotler \& Amstrong . (2012). Prinsip-Prinsip Pemasaran edisi 1 jilid 12. Jakarta. PT Penerbit Erlangga.

Nursita Sari. Irfan Maullana. 06 April 2020. Artikel ini telah tayang di Kompas.com dengan judul "PHK Massal di Tengah Pandemi Covid-19 dan Upaya Pemerintah Berikan Insentif". Jakarta. https://megapolitan.kompas.com/read/2020/04/06/06231941/phk-massal-di-tengahpandemi-covid-19-dan-upaya-pemerintah-berikan?page=all.

Otoritas Jasa Keungan. 2017. Undang-Undang Nomor 20 Tahun 2008 Tentang Usaha Mikro, Kecil, dan Menengah. Jakarta. https://www.ojk.go.id/sustainable-finance/id/peraturan/undangundang/Pages/Undang-Undang-Republik-Indonesia-Nomor-20-Tahun-2008-TentangUsaha-Mikro,-Kecil,-dan-Menengah.aspx

Rosmayani \& Anissa. 2021. Keunggulan Bersaing Berkelanjutan Berbasis Inovasi dan Kearifan Lokal Pada Usaha Kecil dan Menengah Makanan Tradisional di Pekanbaru. Pekan baru Riau. Jurnal Dinamika Lingkungan.

Saori,Sopyan dkk. 2021. ANALISIS KINERJA PEMASARAN PADA INDUSTRI MAKANAN (Studi Kasus UMKM CV. NJ Food Industries, Kabupaten Sukabumi). Kabupaten Sukabumi. Jurnal Inovasi Penelitian

Sharma B. 2004. Marketing strategy, contextual factors and performance: An investigation of their relationship. Marketing Intelligence \& Planning.

Sri \& Nuri. 2022. Strategi Pemasaran STP (Segmenting, Targeting, Dan Positioning) Pada Produk Kecantikan House Of Beauty Cabang Kota Pematangsiantar. Pematang siantar. Jurnal Manajemen

Sugiyono. (2014). Metode Penelitian Pendidikan Pendekatan Kuantitatif, Kualitatif, dan R\&D. Bandung: Alfabeta.

Yandri Daniel Damaledo. 2 Maret 2021. di artikel "2 Maret 2020 Kasus Corona Pertama di Indonesia Diumumkan Tahun Lalu". Jakarta. https://tirto.id/gaKw 